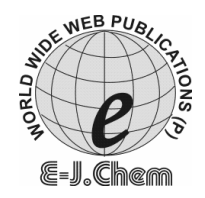

http://www.e-journals.net
ISSN: 0973-4945; CODEN ECJHAO

E-Journal of Chemistry

Vol. 5, No.4, pp. 963-968, October 2008

\title{
Synthesis and Antimicrobial Activities of 1,2,4-Triazole and 1,3,4-Thiadiazole Derivatives of 5-Amino-2-Hydroxybenzoic Acid
}

\author{
SABIR HUSSAIN $^{\S *}$, JYOTI SHARMA ${ }^{\#}$ and MOHD.AMIR ${ }^{\S}$ \\ ${ }^{\S}$ Department of Chemistry, R. R. College, Alwar, Rajasthan. \\ \#Department of Pharmaceutical Chemistry, \\ Jamia Hamdard, New Delhi, India. \\ 03shussain@gmail.com
}

Received 8 May 2008; Revised 19 June 2008; Accepted 23 June 2008

\begin{abstract}
Various 4-amino-2-[4-(4-substituted phenyl)-5-sulfanyl-4H-1,2,4-triazol3-yl] phenol (4a-c), 4-amino-2-\{4-amino-5-[(4-substituted phenyl)amino]-4H-1,2,4triazol-3-yl $\}$ phenol (5a-c) and 4-amino-2-\{5-[(4-substituted phenyl)amino]-1,3,4thiadiazole-2-yl $\}$ phenol (6a-g) were synthesized and evaluated for their antibacterial and antifungal activity. The compounds showed significant antibacterial activity against S. aureus (gram-positive) and E.coli (gram-negative) bacteria and antifungal activity against $A$. niger fungi using cup plate technique
\end{abstract}

Keywords: 1,2,4-Triazole, 1,3,4-Thiadiazole, Antibacterial, Antifungal.

\section{Introduction}

Several five membered aromatic systems having three hetero atoms at symmetrical position have been studied because of their interesting physiological properties ${ }^{1,2}$. It is also well established that various derivatives of 1,2,4-triazole, 1,3,4-thiadiazole exhibit broad spectrum of pharmacological properties such as antibacterial and antifungal activities $^{3,4}$. The available therapeutically important medicines are terconazole, itraconazole, fluconazole, cefazoline and ribavirin etc. are some of the examples which contain one of these heterocyclic nucleus. In view of the above mentioned facts and in continuation of our work on the synthesis of biologically important heterocyclic compounds $^{5-7}$, we describe herein the synthesis of some triazole, thiadiazole derivatives and evaluation of their antimicrobial activities. The reaction sequence leading to the formation of desired heterocyclic compounds are outlined in Scheme 1. The structures of the compounds were assigned on the basis of IR, ${ }^{1} \mathrm{H}$ NMR spectral data. 
<smiles>CCOC(=O)c1cc(N)c(C(=O)O)cc1O</smiles>

(1)

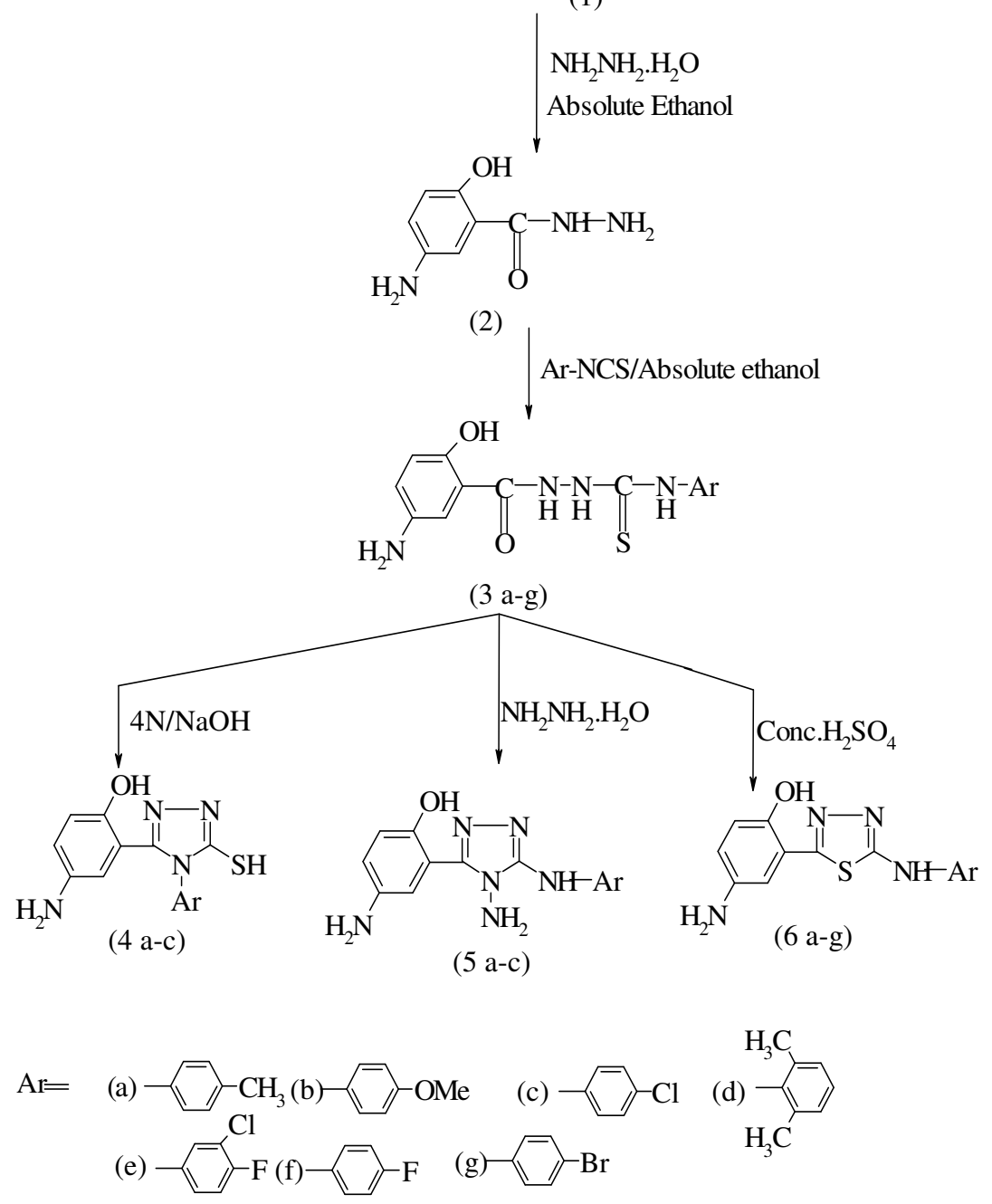

\section{Experimental}

\section{Scheme 1}

Melting points were determined in open capillary tubes. IR spectra were recorded on a Perkin-Elmer 157 spectrometer and ${ }^{1}$ HNMR spectra on a Bucker WM-400 (400 MHZ FT NMR) spectrophotometer using TMS (Tetramethyl Silane) as internal reference (chemical shift in $\delta$ ppm). Purity of the compounds was checked by TLC (Thin Layer Chromatography) on silica gel plates and spot were visualized by exposure to iodine vapours. The physical data of the compounds prepared are presented in Table 1. 
Table 1. Characterization data of the compounds

\begin{tabular}{|c|c|c|c|c|c|c|}
\hline Compound & $\mathrm{Ar}$ & $\begin{array}{c}\text { M.P, } \\
{ }^{\circ} \mathrm{C}\end{array}$ & $\begin{array}{c}\text { Yield } \\
\%\end{array}$ & Mol. Formula & $\begin{array}{l}\mathrm{N}, \% \\
\text { Found }\end{array}$ & Calcd. \\
\hline $4 a$ & & 244 & 63 & $\mathrm{C}_{15} \mathrm{H}_{14} \mathrm{~N}_{4} \mathrm{OS}$ & 18.80 & 18.78 \\
\hline $4 b$ & & 247 & 67 & $\mathrm{C}_{15} \mathrm{H}_{14} \mathrm{~N}_{4} \mathrm{O}_{2} \mathrm{~S}$ & 17.95 & 17.82 \\
\hline $4 c$ & & 253 & 70 & $\mathrm{C}_{14} \mathrm{H}_{11} \mathrm{ClN}_{4} \mathrm{OS}$ & 17.75 & 17.58 \\
\hline $5 a$ & & 240 & 57 & $\mathrm{C}_{15} \mathrm{H}_{16} \mathrm{~N}_{6} \mathrm{O}$ & 28.45 & 28.36 \\
\hline $5 b$ & & 242 & 61 & $\mathrm{C}_{15} \mathrm{H}_{16} \mathrm{~N}_{6} \mathrm{O}_{2}$ & 26.88 & 26.91 \\
\hline $5 c$ & & 238 & 65 & $\mathrm{C}_{14} \mathrm{H}_{13} \mathrm{ClN}_{6} \mathrm{O}$ & 26.65 & 26.53 \\
\hline $6 a$ & & 282 & 68 & $\mathrm{C}_{15} \mathrm{H}_{14} \mathrm{~N}_{4} \mathrm{OS}$ & 18.91 & 18.78 \\
\hline $6 b$ & & 287 & 61 & $\mathrm{C}_{15} \mathrm{H}_{14} \mathrm{~N}_{4} \mathrm{O}_{2} \mathrm{~S}$ & 17.88 & 17.82 \\
\hline $6 c$ & & 278 & 58 & $\mathrm{C}_{14} \mathrm{H}_{11} \mathrm{ClN}_{4} \mathrm{OS}$ & 17.80 & 17.58 \\
\hline $6 \mathrm{~d}$ & & 281 & 65 & $\mathrm{C}_{16} \mathrm{H}_{16} \mathrm{~N}_{4} \mathrm{OS}$ & 18.10 & 17.93 \\
\hline $6 e$ & & 268 & 67 & $\mathrm{C}_{14} \mathrm{H}_{10} \mathrm{ClFN}_{4} \mathrm{OS}$ & 16.90 & 16.64 \\
\hline $6 f$ & & 265 & 62 & $\mathrm{C}_{14} \mathrm{H}_{11} \mathrm{FN}_{4} \mathrm{OS}$ & 18.83 & 18.53 \\
\hline $6 g$ & & 264 & 59 & $\mathrm{C}_{14} \mathrm{H}_{11} \mathrm{BrN}_{4} \mathrm{OS}$ & 15.42 & 15.42 \\
\hline
\end{tabular}

Synthesis of ethyl 5-amino-2-hydroxybenzoate (1)

To a $100 \mathrm{~mL}$ RB flask, a mixture of 5-amino sylicilic acid $(0.001 \mathrm{~mol})$ and absolute alcohol $(50 \mathrm{~mL})$ were taken. Few drop of conc. $\mathrm{H}_{2} \mathrm{SO}_{4}$ along with a small porcelain chip were added. A condenser was attached to the RB flask fitted with a calcium chloride guard tube to maintain anhydrous condition. The reaction mixture was refluxed for 40 $\mathrm{h}$ on water bath, concentrated under reduced pressure to give the ester. ${ }^{1} \mathrm{HNMR}$ $\left(\mathrm{CDCl}_{3}\right): \delta 1.41\left(\mathrm{t}, 3 \mathrm{H}, \mathrm{CH}_{3}\right), \delta 4.38\left(\mathrm{q}, 2 \mathrm{H}, \mathrm{OCH}_{2}\right), \delta$ 7.48-7.64 (m, 3H, Ar- $\left.\mathrm{H}\right)$. 
Synthesis of 5-amino-2-hydroxybenzohydrazide (2)

To a RB flask, compound 1 (0.01 mol), hydrazine hydrate $(0.2 \mathrm{~mol})$ and absolute alcohol $(50 \mathrm{~mL})$ were taken. A condenser with calcium guard tube was attached to the flask and mixture was refluxed for $60 \mathrm{~h}$ on water bath. The mixture was concentrated, cooled and poured in to crushed ice. It was kept for 3-4 $\mathrm{h}$ at room temperature and solid mass separated out was filtered and dried. ${ }^{1} \mathrm{HNMR}\left(\mathrm{CDCl}_{3}\right): \delta 7.50-7.78(\mathrm{~m}$, $3 \mathrm{H}, \mathrm{Ar}-\mathrm{H}), \delta$ 7.87-7.97 (m, 3H, $\mathrm{CONHNH}_{2}$ )

Synthesis of 2-[(5-amino-2-hydroxyphenyl) carbonyl]-N- (4-methyl) hydrazine carbothioamide (3a)

A mixture of compound $2(0.001 \mathrm{~mol})$ and 4-methylphenyl isothiocyanate $(0.001 \mathrm{~mol})$ in ethanol $(25.0 \mathrm{~mL})$ was refluxed on a water bath for $2 \mathrm{~h}$. The solvent was concentrated and the precipitated product was filtered, dried and recrystalized from methanol. 3a IR (KBr): $3390(\mathrm{~N}-\mathrm{H}), 1620(\mathrm{CONH}), 600(\mathrm{ArH}), 1040(\mathrm{C}=\mathrm{S}) . \quad 3 \mathbf{a}^{1} \mathrm{HNMR}\left(\mathrm{CDCl}_{3}\right): \delta$ 7.12$7.60(\mathrm{~m}, 3 \mathrm{H}, \mathrm{Ar}-\mathrm{H}), \delta$ 7.72-7.83 ( $\mathrm{m}, 3 \mathrm{H}, \mathrm{CONHNHCSNH})$. Other compounds 3b-g were prepared similarly and their characterization data are recorded in Table 1

Synthesis of 4-amino-2-[4-(4-methylphenyl)-5-sulfanyl-4H-1,2,4-triazol-3-yl]phenol (4a)

Compound 3a (0.002 mole) was added to ethanol $(20 \mathrm{~mL})$. To this $\mathrm{NaOH}(4 \mathrm{~N}, 2 \mathrm{~mL})$ was added which resulted in clear solution. It was refluxed for $1 \mathrm{~h}$ and treated with decolorizing charcoal and filtered. The filtrate was cooled and $\mathrm{pH}$ was adjusted to 46 with dilute glacial acetic acid. The mixture was kept aside for $1 \mathrm{~h}$ and the crystals produced were filtered, dried and recrystallised from methanol. Other compounds $\mathbf{4 b , c}$ were prepared similarly and their characterization data are recorded in Table 1 4a IR $(\mathrm{KBr}): 3375(\mathrm{~N}-\mathrm{H}), 1591(\mathrm{C}=\mathrm{N}), 1208(\mathrm{C}=\mathrm{S}) 2935(\mathrm{C}-\mathrm{H}) .4 \mathbf{a}^{1} \mathrm{HNMR}\left(\mathrm{CDCl}_{3}\right): \delta 1.82(\mathrm{~s}$, $3 \mathrm{H}, \mathrm{CH}_{3}$ ), $\delta$ 6.28-7.47 (complex m, $\left.7 \mathrm{Ar}-\mathrm{H}\right), 8.03$ (s, 1H, SH). 4b IR (KBr): $3370(\mathrm{~N}-\mathrm{H})$, $1577(\mathrm{C}=\mathrm{N}), 1216(\mathrm{C}=\mathrm{S}) 2935(\mathrm{C}-\mathrm{H}) .4 \mathrm{4b}^{1} \mathrm{HNMR}\left(\mathrm{CDCl}_{3}\right): \delta 3.48\left(\mathrm{~s}, 3 \mathrm{H}, \mathrm{OCH}_{3}\right), \delta 6.32-$ 7.52 (complex m, 7 Ar-H), 8.08 (s, 1H, SH).

4-Amino-2-\{4-amino-5-[(4-methylphenyl)amino]-4H-1,2,4-triazole-3-yl\}phenol (5a)

Compound 3a $(0.025$ mole $)$ and hydrazine hydrate $(0.025$ mole $)$ was refluxed in methanol for $2 \mathrm{~h}$ at a temperature between $50-60^{\circ} \mathrm{C}$, reaction mixture was cooled and poured over crushed ice. Solid was filtered and recrystallised from methanol. Other compounds $\mathbf{5 b}, \mathbf{c}$ were prepared similarly and their characterization data are recorded in Table 1. 5a IR (KBr): $3298(\mathrm{~N}-\mathrm{H}), 1621(\mathrm{C}=\mathrm{N}), 2923(\mathrm{C}-\mathrm{H})$.

5a ${ }^{1} \mathrm{HNMR}\left(\mathrm{CDCl}_{3}\right): \delta 2.23\left(\mathrm{~s}, 3 \mathrm{H}, \mathrm{CH}_{3}\right), 8.21$ (bs, $\left.1 \mathrm{H}, \mathrm{NH}\right), \delta$ 7.05-7.87 (complex m, 7

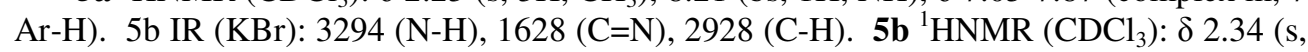
$\left.3 \mathrm{H}, \mathrm{OCH}_{3}\right), 8.26$ (bs, 1H, NH), $\delta$ 7.05-7.68 (complex m, 7 Ar-H).

Synthesis of 4-amino-2-\{5-[(4-methylphenyl) amino]-1,3,4-thiadiazole-2-yl\} phenol (6a)

Compound 3a (0.002 mole) was added portion wise in $5.0 \mathrm{~mL}$ conc. $\mathrm{H}_{2} \mathrm{SO}_{4}$ and stirred with cooling for $2 \mathrm{~h}$. The mixture was poured over crushed ice and the precipitated solid was filtered, washed with water, dried and recrystallised from methanol. Other compounds 6b-g were prepared similarly and their characterization data are recorded in Table 1 6a IR $(\mathrm{KBr}): 3412(\mathrm{~N}-\mathrm{H}), 1615(\mathrm{C}=\mathrm{N}), 2920(\mathrm{C}-\mathrm{H})$. 6a ${ }^{1} \mathrm{HNMR}\left(\mathrm{CDCl}_{3}\right): \delta 3.84\left(\mathrm{~s}, 3 \mathrm{H}, \mathrm{CH}_{3}\right), \delta 6.58-7.53$ (complex m, $7 \mathrm{Ar}-\mathrm{H}$ and $\left.1 \mathrm{NH}\right) .6 \mathrm{~b}$ IR $(\mathrm{KBr}): 3436(\mathrm{~N}-\mathrm{H}), 1624(\mathrm{C}=\mathrm{N}), 2938(\mathrm{C}-\mathrm{H}) .6{ }^{1} \mathrm{HNMR}\left(\mathrm{CDCl}_{3}\right): \delta 3.86\left(\mathrm{~s}, 3 \mathrm{H}, \mathrm{OCH}_{3}\right)$, $\delta$ 6.59-7.55 (complex m, 7 Ar-H and 1NH). 


\section{Result and Discussion}

\section{Spectral characterization of the compounds}

The IR spectrum of the compounds (4a-c) showed peaks at $3375-3361 \mathrm{~cm}^{-1}, \mathrm{~N}-\mathrm{H}$ stretching; 2935-2932 $\mathrm{cm}^{-1}$, CH stretching; $1591-1577 \mathrm{~cm}^{-1}, \mathrm{C}=\mathrm{N}$ stretching and 1216-1208 $\mathrm{cm}^{-1}, \mathrm{C}=\mathrm{S}$ stretching. The NMR spectrum of the compound $\mathbf{4 a}$ showed a singlet at $\delta 1.82$ indicating the presence of $\mathrm{CH}_{3}$ protons. In the aromatic region complex multiplet at $\delta 6.28$ 7.47 was observed indicating the presence of seven aromatic protons. Furthermore a singlet at $\delta 8.03$ was observed for one SH protons. The NMR spectrum of the compound 4b showed a singlet at $\delta 3.48$ indicating the presence of $\mathrm{OCH}_{3}$ protons. In the aromatic region complex multiplet at $\delta 6.32-7.52$ was observed indicating the presence of seven aromatic protons. A singlet at $\delta 8.08$ was observed for one SH protons. The IR spectrum of the compounds (5a-c) showed peaks at $3298-3249 \mathrm{~cm}^{-1}, \mathrm{~N}-\mathrm{H}$ stretching; $2934-2923 \mathrm{~cm}^{-1}$, $\mathrm{CH}$ stretching; 1628-1621 $\mathrm{cm}^{-1}, \mathrm{C}=\mathrm{N}$ stretching. The NMR spectrum of the compound 5a showed a singlet at $\delta 2.23$ indicating the presence of $\mathrm{CH}_{3}$ protons. In the aromatic region complex multiplet at $\delta$ 7.05-7.87 was observed indicating the presence of seven aromatic protons. A broad singlet at $\delta 8.21$ was observed for one $\mathrm{NH}$ protons. The NMR spectrum of the compound 5b showed a singlet at $\delta 2.34$ indicating the presence of $\mathrm{OCH}_{3}$ protons. In the aromatic region complex multiplet at $\delta$ 7.05-7.68 was observed indicating the presence of seven aromatic protons. Furthermore a broad singlet at $\delta 8.26$ was observed for one $\mathrm{NH}$ protons. The IR spectrum of the compounds (6a-g) showed peaks at $3436-3410 \mathrm{~cm}^{-1}$, $\mathrm{N}-\mathrm{H}$ stretching; 2938-2920 $\mathrm{cm}^{-1}$, CH stretching; 1624-1609 $\mathrm{cm}^{-1}, \mathrm{C}=\mathrm{N}$ stretching. The NMR spectrum of the compound 6a showed a singlet at $\delta 3.84$ indicating the presence of $\mathrm{CH}_{3}$ protons. In the aromatic region complex multiplet at $\delta$ 6.58-7.53 was observed indicating the presence of seven aromatic protons and one $\mathrm{NH}$ protons. The NMR spectrum of the compound $\mathbf{6 b}$ showed a singlet at $\delta 3.86$ indicating the presence of $\mathrm{OCH}_{3}$ protons. In the aromatic region complex multiplet at $\delta 6.59-7.55$ was observed indicating the presence of seven aromatic protons and one $\mathrm{NH}$ protons.

\section{Antimicrobial activity}

The synthesized compounds were evaluated for their antimicrobial activity against bacterial strain Staphylococcus aureus (S. aureus) (gram-posative), Escherchia coli (E. coli) (gramnegative) and fungal strain $A$ niger by cup plate method $^{8}$ at $200,100,50$ and $25 \mu \mathrm{g} / \mathrm{mL}$ concentration. Ofloxacin and ketoconazole were used as standard drugs for antibacterial and antifungal activity respectively. The minimal inhibitory concentration (MICs, $\mu \mathrm{gmL}^{-1}$ ) of the tested compounds are recorded in Table 2

The 1,2,4-triazole derivative $\mathbf{4} \mathbf{c}$ having chloro group at para position of phenyl ring exhibited a MIC of $25 \mu \mathrm{g} / \mathrm{mL}$ against A. niger, whereas $4 \mathbf{a}$ exhibited significant antimicrobial activity (MIC $50 \mu \mathrm{g} / \mathrm{mL}$ ) against $S$. aureus, E. coli. The compound 5 a exhibited promising antibacterial activity (MIC $25 \mu \mathrm{g} / \mathrm{mL}$ ) against A.niger strains, whereas 5c exhibited significant antimicrobial activity (MIC $50 \mu \mathrm{g} / \mathrm{mL}$ ) against S.aureus, E. coli and A. niger. The 5-amino-2-hydroxybenzohydrazide derivative 6e having 3-chloro-4fluorophenyl amino group at $2^{\text {nd }}$ position of thiadiazole ring was found to have MIC 25 $\mu \mathrm{g} / \mathrm{mL}$ against $S$. aureus, E.coli and A. niger 1,3,4-thiadiazole derivatives 6c, 6f also exhibited promising antibacterial activity (MIC $25 \mu \mathrm{g} / \mathrm{mL}$ ) against $S$. aureus and A. niger. 
Table 2 . Antimicrobial activities of the compounds.

\begin{tabular}{cccc}
\hline \multirow{2}{*}{ Compounds } & \multicolumn{3}{c}{ MIC, $\mu \mathrm{g} / \mathrm{mL}$} \\
\cline { 2 - 4 } Ofloxacin & S. aureus & E. coli & A. niger \\
Ketoconazole & 10 & 12.5 & -- \\
$\mathbf{4 a}$ & -- & -- & 12.5 \\
$\mathbf{4 b}$ & 50 & 50 & 50 \\
$\mathbf{4 c}$ & 100 & 100 & 100 \\
$\mathbf{5 a}$ & 100 & 50 & 25 \\
$\mathbf{5 b}$ & 50 & 100 & 25 \\
$\mathbf{5 c}$ & 100 & 100 & 50 \\
$\mathbf{6 a}$ & 50 & 50 & 50 \\
$\mathbf{6 b}$ & 50 & 100 & 50 \\
$\mathbf{6 c}$ & 100 & 100 & 50 \\
$\mathbf{6 d}$ & 25 & 50 & 25 \\
$\mathbf{6 e}$ & 100 & 100 & 100 \\
$\mathbf{6 f}$ & 25 & 25 & 25 \\
$\mathbf{6 g}$ & 25 & 50 & 25 \\
\hline
\end{tabular}

-- Not tested

\section{Conclusion}

A total of 13 compounds (06 1,2,4-triazoles and 07 1,3,4-thiadiazoles) were synthesized and screened for their antibacterial activity against S. aureus (gram positive) and E. coli (gram negative) bacteria and antifungal activity against A. niger. The minimal inhibitory concentrations (MIC) of all the compounds were determined by observing the zones of inhibition formed around the cup after $24 \mathrm{~h}$ of incubation for antibacterial and $48 \mathrm{~h}$ for antifungal activities. Compounds were found to have moderate antimicrobial activity.

\section{Acknowledgement}

The authors are thankful to the Head, Department of chemistry, for providing laboratory facilities and to the Head, RSIC-CDRI, Lucknow, for spectral analysis.

\section{References}

1. Hetzhein A and Mockel K, Adv Heterocycle Chem., 1996, 7, 183.

2. Sandstrom J, Adv. Heterocycle Chem., 1968, 9, 165.

3. Hosam Saad, Indian J Chem., 1996, 35B, 980.

4. Hui XP, Chu C H, Zang ZY, Wang Q and Zhang Q, Indian J Chem., 2002, 41B, 2176.

5. Amir M, Dhar N \& Tiwari S K, Indian J Chem., 1997, 36B, 96.

6. Amir M and Shahani S, Indian J Chem., 1998, 37B, 502.

7. Amir M, Oberoi A and Alam S, Indian J Chem., 1999, 38B, 237.

8. Barry AL, The antimicrobial susceptibility test: principle and practices, Edited by Illuslea and febiger, (Philadelphia, USA) 1976, 180; Biol Abstr, 1977, 64, 25183. 


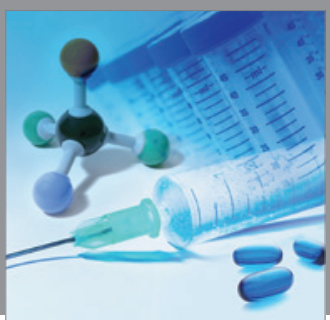

International Journal of

Medicinal Chemistry

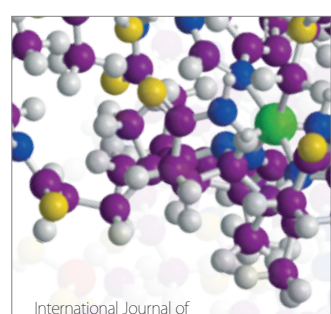

Carbohydrate Chemistry

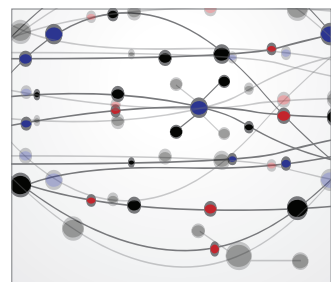

The Scientific World Journal
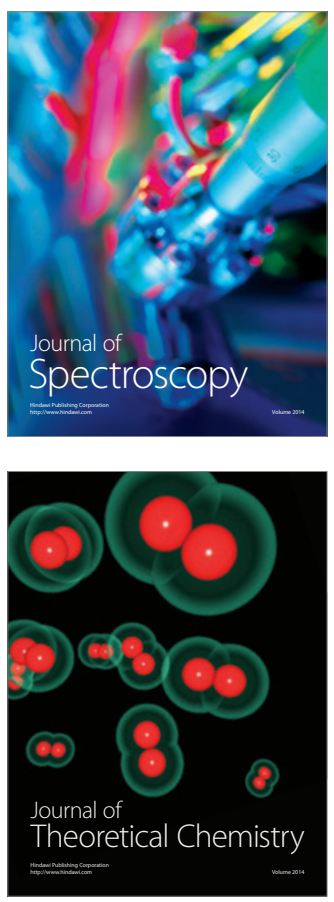
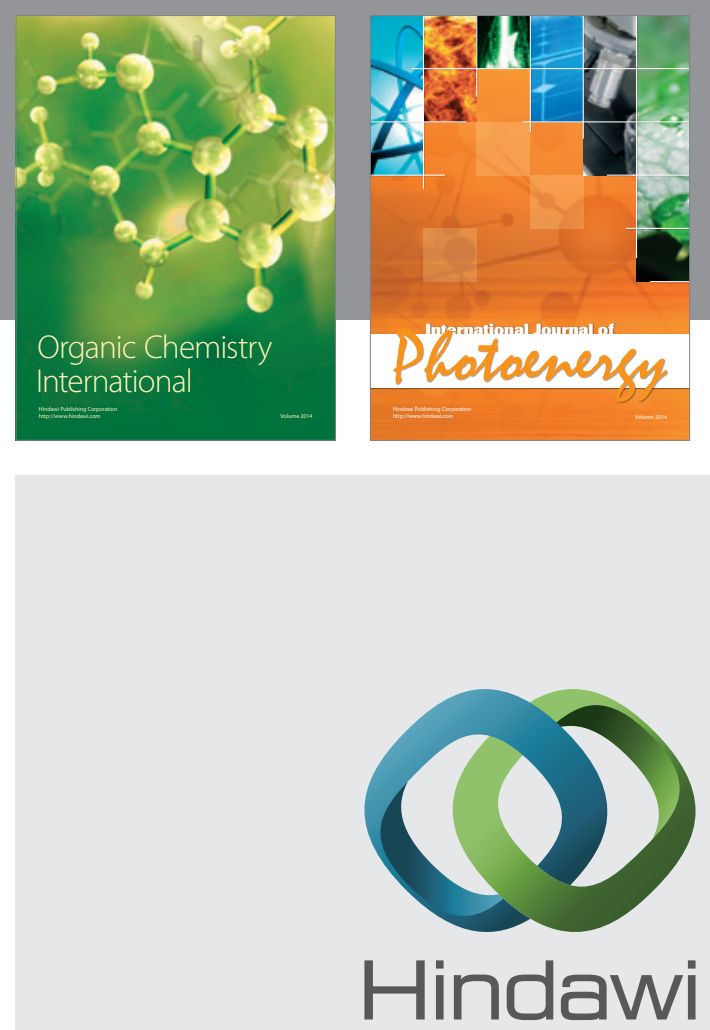

Submit your manuscripts at

http://www.hindawi.com
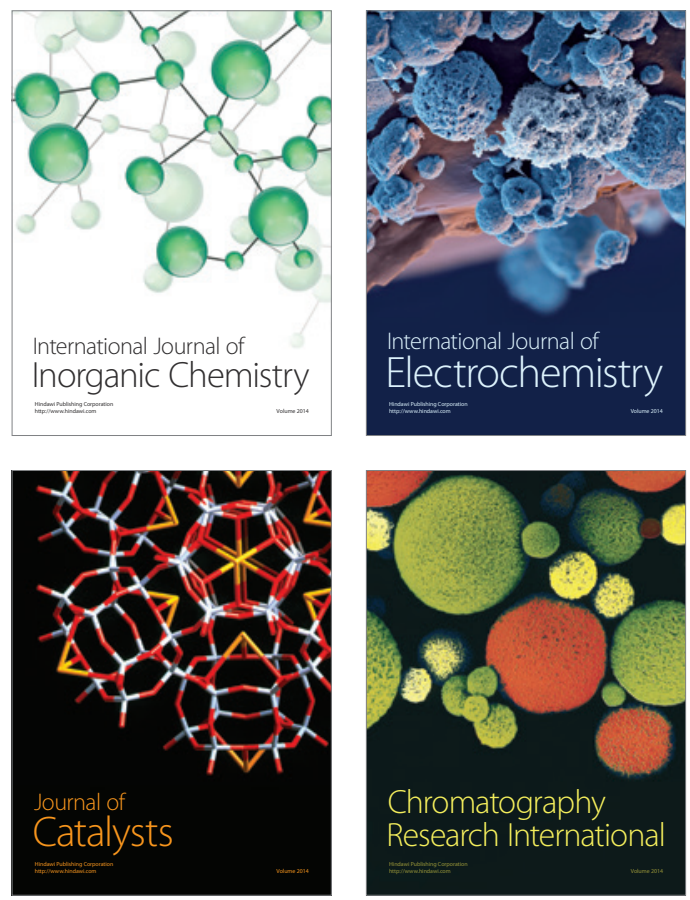
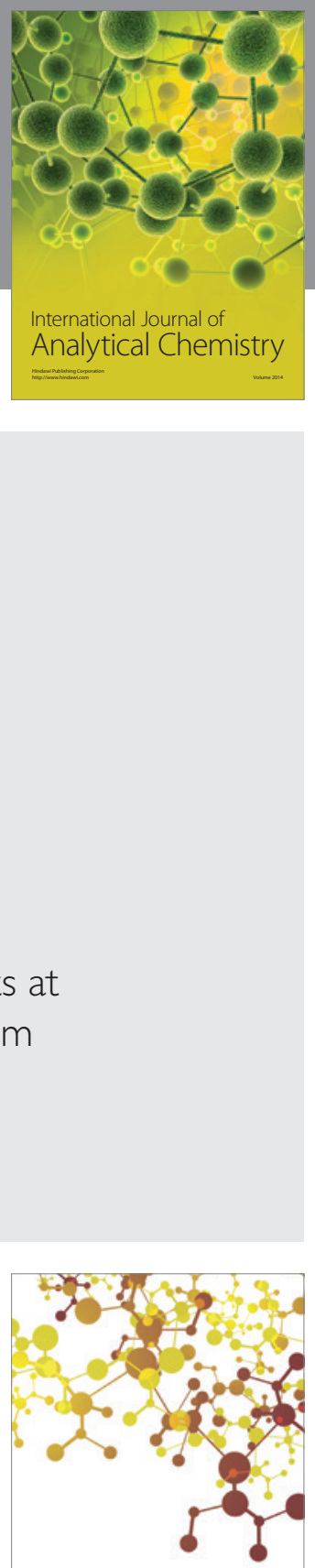

Journal of

Applied Chemistry
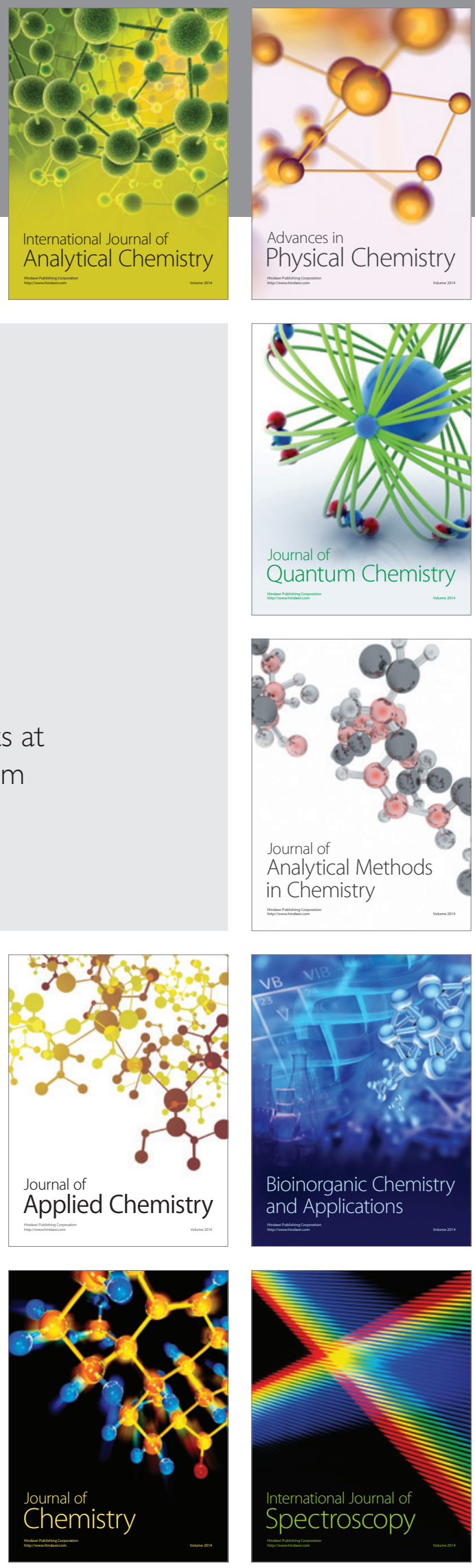